\title{
THE VALUATION OF ASSET MANAGEMENT FIRMS
}

\author{
Marco Bigelli *, Fabio Manuzzi ** \\ * Corresponding author, University of Bologna, Italy \\ Contact details: Via Zamboni, 33, 40126 Bologna BO, Italy \\ ** University of Bologna, Italy
}

OPEN ACCESS
How to cite this paper: Bigelli, M., \&
Manuzzi, F. (2019). The valuation of asset
management firms. Corporate Ownership
\& Control, 16(4), 103-1 10.
http://doi.org/10.22495/cocvl6i4art9
Copyright @ 2019 The Authors
This work is licensed under a Creative
Commons Attribution 4.0 International
License (CC BY 4.0$).$
https://creativecommons.org/licenses/by/
4.0/
ISSN Online: 1810-3057
ISSN Print: 1727-9232
Received: 24.04 .2019
Accepted: 26.07 .2019
JEL Classification: G14
DOI: 10.22495/cocv16i4art9

How to cite this paper: Bigelli, M., \& Manuzzi, F. (2019). The valuation of asset $\&$ Control, 16(4), 103-110.

http://doi.org/10.22495/cocvl6i4art License (CC BY 4.0).

ttps://creativecommons.org/licenses/by/

ISSN Online: 1810-3057

Received: 24.04 .2019

Accepted: 26.07 .2019

DOI: $10.22495 / \operatorname{cocv} 16 i 4 a r t 9$

\begin{abstract}
After reviewing the main valuation frameworks of asset management firms, we ran empirical research on 50 listed US and European asset management firms in the 2008-2017 period. Our results find that such firms are characterized by a high EBIT and earnings margin, respectively equal, on average, to $28 \%$ and $17 \%$ of revenues, represented by fees. The average yearly fees are equal to $1.04 \%$ of assets under management (AUM) and the average firm value is equal to $3.01 \%$, confirming the values at which these companies are typically acquired on the market. Higher values are found to be significantly positively correlated with a higher earnings margin and a higher level of fees on AUM, confirming the previous findings of Joenväärä and Scherer (2017) on a smaller US sample.
\end{abstract}

Keywords: Asset Management, Valuation, Assets under Management, Revenues, Multiples

Authors' individual contribution: Conceptualization - M.B. and F.M.; Methodology - M.B. and F.M.; Writing - M.B.; Investigation - F.M.; Funding - M.B.; Resources - M.B.; Supervision - M.B.

\section{INTRODUCTION}

Asset management has been one of the fastest growing industries in the financial industry. Malkiel (2013) reports that from 1980 to 2010 the mutual fund industry in the US multiplied its assets under management (AUM) by 135 times, passing from $\$ 26$ billion to $\$ 3.5$ trillion of AUM. Academic literature has addressed how multiples can be used in firm valuation (Lie \& Lie, 2002; Liu et al., 2002), how the selection of comparable firms can be relevant (Alford, 1992; Bhojraj \& Lee 2002; Eberhart, 2004), how the comparable company method should be adjusted for the value of corporate control (Finnerty \& Emery, 2004), how emerging markets may have specifics factors affecting multiples (Farah Freihat, 2019), how some multiples can be combined to obtain a better estimate (Yoo, 2006), how firm's value in different industries is better proxied by different multiples (Fidanza, 2010), and which multiples work better for banks' valuation (Forte et al., 2019). The multiple given by the market capitalization to assets under management (P/AUM) is the most adopted methodology for pricing firms in the asset management industry. Zask (2005) reports that Berkshire Capital analyzed a sample of US asset management firms in the 1993-1999 period, finding that their values ranged between $2 \%$ and $3 \%$ of assets under management (AUM). In a sample of only 10 US asset managers listed at the end of 2002, Huberman (2006) finds an average P/AUM equal to $3.51 \%$. A research report by Lehman Brothers made by Constant (2004), analyzes 66 acquisitions of asset management firms in the 1997-2004 period and finds that $90 \%$ of the time the entire equity stake was purchased at a price ranging between $0.2 \%$ and $5 \%$ of assets under management and at an average value of 3.2\%. More recently, Joenväärä and Scherer (2017) analyse 33 firms listed on the US market in the 1998-2013 period and find an average P/AUM ranging between $0.4 \%$ and $5.5 \%$, significantly correlated both with a higher earnings margin and with a higher percentage level of fees on AUM.

The main purpose of this paper is to refine the empirical analysis made by Joenväärä and Scherer (2017), again looking at the value of asset management firms and its determinants, but on a more select sample, represented only by firms without any activity other than asset management and extended to European firms. The sample analysed by Joenväärä and Scherer (2017), in fact, only covered US firms and included firms also involved in private equity and M\&A, such as Apollo Global Management, KKR and The Blackstone Group and the results could have been driven by outliers related to the firms not being pure asset management firms. In addition, in order to examine a larger and more international sample, we are the 
first to analyse not only a sample of US firms but also a sample including both US and European firms, together with some new explanatory variables.

After reviewing the main valuation frameworks of asset management firms, we ran empirical research on 50 US and European asset management firms listed on a stock exchange in the 2008-2017 period. One contribution of the paper is to analyse the profitability of the asset management firms listed on both the US and the EU markets. In fact European asset management firms are characterized by a higher average level of fees on AUM than US firms (1.23\% versus $0.94 \%)$ and a higher level of net earnings margin (17.76\% versus $16.34 \%$ ), leading to an average higher value as a proportion of AUM (3.73\% versus $2.61 \%)$. A second contribution of the paper is to test the value-drivers of the asset management firms on an international and strictly selected sample. Our results find that such firms are characterized by a high EBIT and Earnings margin, respectively equal on average to $28 \%$ and $17 \%$ of revenues, represented by total fees. The average yearly growth rate of revenues, EBIT and net earnings are respectively equal to $8 \%, 9 \%$ and $1 \%$. The average yearly fees are equal to $1.04 \%$ of AUM and the average firm value is equal to $3.01 \%$ of AUM, confirming the average values at which this type of company is usually acquired on the market Constant (2004). Higher values are also found to be significantly correlated with a higher earnings margin and a higher level of fees on AUM, confirming the previous findings of Joenväärä and Scherer (2017). US or EU asset management firms tend to be evaluated at a similar percentage of their AUM when controlling for the two major determinants of their value, i.e. the level of fees on assets under management and the earnings margin.

The remainder of the paper is structured in the following way: in the next paragraph we review the two main valuation methods for the asset management firms; in the third paragraph we describe the sample's construction and the variables used in the multivariate analysis; in the fourth paragraph we report and comment on the empirical results; in the fifth we summarize our conclusions.

\section{THEORETICAL APPROACHES TO AN ASSET MANAGEMENT FIRM VALUATION}

Damodaran (2013) highlights that it is not easy to estimate cash flows made by financial firms (not only asset management firms, but also banks, insurance firms, etc.), because, besides working in a regulated framework, cash flows to the firms cannot be easily estimated, since items like capital expenditures, working capital and debt are not clearly defined. He, therefore, concludes that financial service firms are best valued using equity valuation models, rather than enterprise valuation models. When we evaluate an asset management firm it is also reasonable to assume that Free Cash Flows to Equity-holders (FCFE) are proxied by net earnings, because of a negligible level of investments, depreciation and net working capital. In fact, earnings are used as an estimate of the FCFE both by Huberman (2006) and Joenväärä and Scherer (2017), who developed the two models that we are going to show and review below.

Asset management firms are characterized by having quite high margins, although working in a highly competitive industry. Huberman (2006) reports that the firms in his sample showed an average EBIT margin equal to 38\% of revenues and a net margin (earnings/revenues) equal to $21 \%$. A similar average net margin level is found in their sample by Joenväärä and Scherer (2017) and is equal to $17 \%$.

Using the same intuitive notation adopted by Joenväärä and Scherer (2017), the net earnings by an asset management firm can be determined as the product of three components - the assets under management $(A U M)$, the ratio of fees on AUM $(f)$, and the earnings margin, given by the ratio of the net earnings on total fees, $(q)$, i. e.:

$$
\text { Net earnings }=A U M * \frac{\text { fees }}{A U M} * \frac{\text { Net earnings }}{\text { fees }}=A U M * f * q
$$

Huberman (2006) adapts the Discounted Cash Flow model (DCF) to asset management firms and concludes that the $2-4 \% \mathrm{P} / \mathrm{AUM}$ ratio at which asset management firms are usually traded is relatively low, as their value on AUM should be closer to the earnings margin $(q)$, which is usually around a $20 \%$ value. His model is based on the following hypothesis:

- net earnings equal the Free Cash Flow to Equity-holders;

- assets under management have already reached a steady state. No money flows into or out from managed assets with the exception of the management fees which are debited on a yearly basis. All dividends and capital gains are reinvested in the managed mutual funds or in the managed clients' portfolios;

- the level of fees on AUM is equal to " $f$ " as in Equation (1);

- the assets under management, net of transaction costs, but gross of (management) fees, yield a yearly return equal to " $r$ ";
- the discount rate of the cash flows, "R", is equal to the return on the assets under management, " $r$ ".

Given the above hypothesis, using the more intuitive notation from Joenväärä and Scherer (2017), the Huberman model can be explained in the following way. Net earnings at the end of the first year can be defined as:

$$
\text { Net earnings } s_{1}=A U M *(1+r) * f * q
$$

While earnings at the end of a generic year "i" can be defined as:

$$
\text { Net earnings } s_{i}=A U M *(1+r)^{i} *(1-f)^{i-1} * f * q
$$

As a result of the above hypothesis, assuming that net earnings are equal to the FCFE, by discounting FCFEs at the Equity cost of capital $(R)$, the following discounted cash flow model follows: 


$$
P V_{0}=\frac{A U M(1+r) f q}{(1+R)}+\frac{A U M(1+r)^{2}(1-f) f q}{(1+R)^{2}}+\ldots+\frac{A U M(1+r)^{n}(1-f)^{n-1} f q}{(1+R)^{n}}+\cdots
$$

Assuming that the returns on the assets under management $(r)$ is equal to the equity cost of capital of the firm $(R)$, after some mathematical simplifications, Equation (4) can be reduced to the following:

$$
P=P V_{0}=A U M * q *\left[1-(1-f)^{n-1}\right]
$$

In addition, by considering an infinite valuation horizon $(\mathrm{n}=\infty)$, and rearranging the equation so as to have the P/AUM ratio on the left-hand side, the model can finally be reduced to the following final result:

$$
\frac{P}{A U M}=q
$$

Since the earning margin, $q$, is, on average, around 20\%, while asset management firms are usually priced about 2-4\% of AUM, Huberman (2006) concludes that they somehow quote at a discount. According to this model, the value seems to be insensitive to the level of fees because an increase in fees will increase the earnings in the short run at the expense of earnings in the long run, and the two effects offset each other when the asset growth rate (gross of fees), " $r$ ", is equal to the discount rate " $R$ ".

However, this hypothesis obviously seems strong and unrealistic, as the average return of assets under management should be lower than the equity cost of capital because assets under management are also composed of bonds and money market portfolios. Besides, the risk of equity of an asset management firm is anyway amplified by operational and regulatory risk.

The equivalence between the perpetual return of the assets under management and the equity cost of capital of the firm is also identified as the main limit of Huberman's model by Joenväärä and Scherer (2017). They also argue that it cannot be assumed that the level of assets under management increases ad infinitum, as the investment industry suffers from diseconomy of scales, as shown by Berk and Green (2004). Latzko (2014) also empirically reports that economy of scales in mutual fund administration vanishes when about $\$ 3.5$ billion in fund assets is reached. Joenväärä and Scherer (2017) therefore amend Huberman's model, and by assuming that the asset management firm has already reached its optimal size they introduce the hypothesis that assets under management are constant over time, eliminating the previous assumption of a yearly gross revaluation at a yearly rate equal to " $r$ ". In this way, by assuming that the level of fees and the net margin are also constant over time, the net earnings also become constant over time. The net earnings made in year $i$ can therefore be expressed in the following way:

$$
\text { Net earnings } s_{i}=A U M * f * q
$$

Assuming again net earnings equal to the FCFE, the present value of the discounted stream of future perpetual cash flows becomes as follows:

$$
\begin{gathered}
P=P V_{0}=\lim _{n \rightarrow \infty}\left[\frac{A U M * f * q}{1+R}+\frac{A U M * f * q}{(1+R)^{2}}+\ldots+\frac{A U M * f * q}{(1+R)^{n}}\right] \\
P=A U M * f * q *\left[\frac{1}{1+R}+\frac{1}{(1+R)^{2}}+\ldots+\frac{1}{(1+R)^{n}}\right] \\
P=A U M * f * q *\left[\frac{\frac{1}{1+R}-\frac{1}{(1+R)^{n+1}}}{1-\frac{1}{1+R}}\right] \\
P=A U M * f * q * \frac{1}{R}
\end{gathered}
$$

If we express the final equation indicating the $\mathrm{P} / \mathrm{AUM}$ on the left-hand side, the results become more easily comparable with those of the previous model, as in the following equation:

$$
\frac{P}{A U M}=f * q * \frac{1}{R}
$$

The Price/AUM ratio is therefore simply given by the present value of perpetuity whose perpetual cash flow is the product of the level of fees on AUM $(f)$ and the net margin $(q)$. The model developed by Joenväärä and Scherer (2017) results in valuations of asset management firms in line with the empirical ones observed on the market. In fact, if we take some hypothetical values not far from real ones and we set a level of fees equal to $1 \%$ of assets under management $(f)$, a net margin equal to $20 \%(q)$ and a discount rate equal to $6 \%(R)$, the resulting multiple $\mathrm{P} / \mathrm{AUM}$ would be equal to $3 \%$, a value very similar to the average one observed on the market and in the acquisitions of asset management firms (Zask, 2005, Constant, 2004).

One inconsistency of their model, however, is that they indicate a risk-free rate as the discount rate $(R)$ of the constant stream of earnings or cash flows, probably as a consequence of the constant perpetual cash flow in their model. However, since they contemporarily report that 29 firms out of the 33 in their sample were characterized by a beta greater than one, a risk-adjusted cost of equity seems to be a more appropriate discount rate.

\section{SAMPLE AND VARIABLE DEFINITION}

Our initial sample is initially based on all management firms listed on the US and European stock markets in the 2008-2017 period. The sample has then been limited to those firms involved 
exclusively in asset management by excluding those firms which were also running other activities, such as investment banking, brokerage, proprietary trading, insurance, etc.

We initially identified 74 firms classified as investment management firms and fund operators on Eikon by Thomson Reuters. Each firm then became the object of a first screening so as to exclude those asset management firms also involved in other activities. The data used in the following analysis were then taken from both Eikon and Datastream. In order to have a panel data as balanced as possible, some of the missing values in the data providers were hand-collected either from the financial reports or from other official documents available in the investor relation section of the firm's website. A second accurate analysis of those firms presenting anomalous levels of revenues over AUM allowed us to pinpoint some more firms involved in other activities different from asset management. The final sample is made up of 50 pure asset management firms, 32 of which are US and 18 European, for which we have retrieved or computed the following variables:

- Market Cap = firm's market capitalization.

- $A U M=$ firm's assets under management.

- Price $/ A U M=$ firm's market capitalization divided by its assets under management.

- $\quad F e e s / A U M=$ firm's yearly revenues divided by its assets under management.

- EBIT Margin = ratio between EBIT and total revenues.

- Net Margin = ratio between net earnings and total revenues.

- Revenues growth = yearly (year on year) revenues' growth rate.

- EBIT growth = yearly (year on year) EBIT's growth rate.

- Net Income Growth = yearly (year on year) net earnings' growth rate.

- Dummy_US is a dummy variable equal to 1 if the firm is a US firm and equal to 0 if it is European.

- D_2012 is a dummy variable equal to 1 for observations in the 2013-2017 period and equal to 0 for observations in the 2008-2012 period, in order to take into consideration a possible higher level of prices due to lower interest rates following the central banks' quantitative easing after the European government bonds crisis.

\section{EMPIRICAL RESULTS}

\subsection{Descriptive statistics}

Descriptive statistics of the above variables for our unbalanced panel data sample are reported in Table 1 . The market capitalization ranges from 11 million to 82.4 billion US dollars (Blackrock) and averages $\$ 5.5$ billion. The average (median) value of assets under management is $\$ 287.9$ billion (\$69.2), ranging from less than a billion to more than 6 trillion (see Table 1 in Appendix).

The average value of the asset management firms in our sample is equal to $3.01 \%$, in line with the findings by previous researches (Zask, 2005;
Huberman, 2006; Joenväärä \& Scherer, 2017). The average level of the total yearly fees is equal to $1.04 \%$ of assets under management. The average EBIT margin and Net margin respectively are equal to $27.83 \%$ and $16.84 \%$ of revenues (i.e. total fees in our sample), while their year-on-year growth rates present a very high dispersion.

If we insert the average values that we found in the Equation (13) and then solve for the cost of equity we find the following:

$$
\frac{P}{A U M}=f * q * \frac{1}{K_{e}}=1.04 \% * 16.84 \% * \frac{1}{5.82 \%}=3.01 \%
$$

The average observed value of Price/AUM, given the level of fees and net margin, would be compatible with an average cost of equity equal to $5.82 \%$, which is quite close to the cost of equity reported by Damodaran for the US banking industry (equal to 6.07\%). ${ }^{2}$ Viceversa, using an average $6.07 \%$ discount rate, we would obtain an average Price/AUM equal to $2.89 \%$, close to the $3,01 \%$ average value empirically observed in our sample:

$\frac{P}{A U M}=f * q * \frac{1}{K_{e}}=1.04 \% * 16.84 \% * \frac{1}{6.07 \%}=2.89 \%$

These values, therefore, offer some preliminary evidence that the main value drivers of the Price/AUM multiple are the level of fees on AUM (Fees/AUM) and the earnings profitability (Net Margin) of the asset management firm.

When the sample is split between US and EU firms, Table 2 shows that, on average, US firms are larger in market capitalization as they manage a larger amount of assets. However, smaller European asset management firms are characterized by a higher average level of fees on AUM (1.23\% versus $0.94 \%$ ) and a higher level of net earnings margin (17.76\% versus $16.34 \%$ ), and these are probably the reasons why they show an average higher valuation multiple of Price/AUM (3.73\% versus 2.61\%) (see Table 2 in Appendix).

\subsection{Log-transformation, winsorization and correlation analysis}

Since the following variables Price/AUM, Fees/AUM and $A U M$ are found to be right-skewed distributed, in order to obtain more symmetrical distributions we decided to use their log transformations. We have also winsorized the variables EBIT growth and Net Income growth at $2.5 \%$ of each tail, and the variables Revenues growth, EBIT Margin and Net Margin at $1 \%$ of each tail. Table 3 (see Appendix).reports the new descriptive statistics of the above-winsorized variables.

The average winsorized yearly growth rate of revenues, of EBIT and of net earnings are respectively equal to $8.05 \%, 9.34 \%$ and $1.19 \%$, while the winsorized EBIT margin and net margin are now slightly higher and respectively equal to $28.04 \%$ and $17.13 \%$.

In order to check for some potential linear correlation between some of the explanatory variables, we used a pair-wise Pearson correlation matrix reported in Table 4 (see Appendix).

\footnotetext{
This is because for the firms in our sample revenues are represented only by fees, being our firms not involved in non-characteristic activities.

See: http://people.stern.nyu.edu/adamodar/New_Home_Page/datafile/wacc.htm 
Since the two variables EBIT Margin and Net Margin were highly positively correlated $(\rho=0.75)$, we decided to use only the second one in the following multivariate analysis, as according to the above models it is supposed to be one of the major determinants of the P/AUM multiple. As far as the growth variable is concerned, we have similarly decided to use only the Revenues growth as the EBIT growth and Net Income growth variables appear to be somehow correlated with other explanatory variables, probably for some of their extreme values notwithstanding their winsorization.

\subsection{Multivariate analysis}

Using the Price/AUM as the independent variable, we tried to explain its major determinants through some multivariate unbalanced panel regressions in a fixed effect model with cluster-robust standard errors to correct for heteroscedasticity in the residual terms. In fact, we first ran the Hausman specification test (Hausman, 1978), which, at the 1\% confidence level, always rejected the hypothesis that a random effects model is an efficient estimator compared with a fixed effect model. We also previously test for homoscedasticity of residual terms, which was always rejected. Table 5 (in Appendix) reports the results for our models.

As expected, the variables Log Fees/AUM and Net Margin are positively and significantly correlated with the value of an asset management firm expressed by the multiple Price/AUM, therefore confirming the previous findings by Joenväärä and Scherer (2017). The dummy variable for post-2012 observations (D_2012) presents positive but not significant values both in models 2 and 4 , where it is used as an explanatory variable. The growth of revenues does not seem to be significant, probably as the growth is sensitive to changes in AUM due to market movements and to possible performance fees which are not necessarily going to be repeated in the following years. The size variable ( $\log A U M)$ shows a negative but insignificant correlation with the valuation multiple, maybe because the larger US firms are characterized by lower values due to their lower profitability.

\subsection{Robustness test}

As a Robustness test, we run the same regressions in a model with random effects and cluster robust errors, where we could also include the Dummy_US variable, which could not be included in the previous fixed effect model, as it is time invariant. Results are reported in Table 6 (in Appendix).

The results greatly confirm the previous findings regarding the fixed effect model as the variables Log Fees/AUM and Net Margin are again always positively and significantly correlated with the firm's value expressed by the Price/AUM multiple. All the other explanatory variables keep the same sign found by the previous model, though they all appear not to be statistically significant (the only $\log A U M$ presents a $10 \%$ significant level in model 4). The dummy for US firms presents slightly negative coefficients which are not statistically significant, indicating that US or EU asset management firms tend to be valued at a percentage similar to their AUM when controlling for the two major determinants of their value, i.e. the level of fees on assets under management and the earnings margin.

\section{CONCLUSIONS}

The results from an empirical analysis on a sample of 50 US and European pure asset management firms in the 2008-2017 period found that the average yearly fees are equal to $1.04 \%$ of assets under management, the earnings margin averages $16.84 \%$ of total revenues and the average firm value is equal to $3.01 \%$ of assets under management, aligned with the values at which these companies are acquired on the M\&A market (Constant, 2004). European asset management firms are characterized by a higher average level of fees on AUM than US firms (1.23\% versus $0.94 \%)$ and a higher level of the net earnings margin (17.76\% versus $16.34 \%)$ which lead to an average higher value as a proportion of AUM (3.73\% versus 2.61\%).

The average values we found for the multiple Price/AUM, the average fee level and the average earnings margin seem to fully support the simple valuation model proposed by Joenväärä and Scherer (2017). In fact, if we use our average reported values as inputs for their model together with the cost of capital for the banking industry we would obtain an average value of the asset management firms equal to $2.89 \%$ of assets under management, pretty close to the $3.01 \%$ that we have empirically observed in our sample. The results from the multivariate analysis found that the P/AUM multiples of asset management firms are significantly determined by higher earnings margins and higher levels of fees on AUM, further confirming the model by Joenväärä and Scherer (2017) in our wider and more international sample. Our results, in fact, confirm that US or EU asset management firms tend to be valued at a percentage similar to their AUM, after controlling for the two major determinants of their value, i.e. the level of fees on assets under management and the earnings margin.

Future research can overcome some limitations of this study and extend the analysed sample on a global basis and over a longer studied period, to check for patterns in valuation multiples, and for possible links with macroeconomic and regulatory variables (for example, the so-called MIFID2 European directive, 2014/65/EU, in force since 2018, is expected to significantly reduce the profitability of asset management firms).

\section{REFERENCES}

1. Alford, A.W. (1992). The effect of the set of comparable firms on the accuracy of the price-earnings valuation method. Journal of Accounting Research, 30(1), 94-108. https://doi.org/10.2307/2491093

2. Berk, J. B., \& Green, R. C. (2004). Mutual fund flows and performance in rational markets. Journal of Political Economy, 112(6), 1269-1295. https://doi.org/10.1086/424739

3. Bhojraj, A., \& Lee, C. M. C. (2002). Who is my peer? A valuation-based approach to the selection of comparable firms. Journal of Accounting Research, 40(2), 407-439. https://doi.org/10.1111/1475-679X.00054

$$
\text { VIRTUS }
$$


4. Constant, M. I. (2004). Brokers and asset managers, September Quarter Broker/Investment Bank Earnings Preview. Lehman Brothers Report, October 14th 2014.

5. Damodaran, A. (2013). Valuing financial service firms. Journal of Financial Perspectives, 1, 59-74.

6. Eberhart, A. C. (2004). Equity valuation using multiples. Journal of Investing, 13, $48-54$. https://doi.org/10.3905/joi.2004.412306

7. Farah Freihat, A. R. (2019). Factors affecting price to earnings ratio (P/E): Evidence from the emerging market. Risk Governance and Control: Financial Markets \& Institutions, 9(2), 47-56. https://doi.org/10.22495/rgcv9i2p4

8. Fidanza, B. (2010). The valuation by multiples of Italian firms. Corporate Ownership \& Control, 7(3-1), 228-241. https://doi.org/10.22495/cocv7i3clp7

9. Finnerty, J. D., \& Emery, D. R. (2004). The value of corporate control and the comparable company method of valuation. Financial Management, 33, 91-99.

10. Forte, G., Gianfrate, G., \& Rossi, E. (2019). Does relative valuation work for banks? Global Finance Journal, forthcoming. https://doi.org/10.1016/j.gfj.2018.09.002

11. Hausman, J. A. (1978). Specification tests in econometrics. Econometrica, 46(6), 1251-1271. https://doi.org/10.2307/1913827

12. Huberman, G. (2004). What is the NPV of expected future profits of money managers? Working Paper, Columbia University. Retrieved from https://www.coursehero.com/file/p1f919g/Huberman-G-2004-What-Isthe-NPV-of-Expected-Future-Profits-of-Money-Managers/

13. Huberman, G. (2006). Is the price of money managers too low? Working paper, Columbia Business School. https://doi.org/10.2139/ssrn.912774

14. Joenväärä, J., \& Scherer, R. (2017). A note on the valuation of asset management firms. Journal of Financial Markets and Portfolio Management, 31(2), 181-199. https://doi.org/10.1007/s11408-017-0287-y

15. Latzko, D. A. (1999). Economies of scale in mutual fund administration. Journal of Financial Research, 22(3), 331-339. https://doi.org/10.1111/j.1475-6803.1999.tb00731.x

16. Lie, E., \& Lie, H. J. (2002). Multiples used to estimate corporate value. Financial Analyst Journal, 58(2), 44-54. https://doi.org/10.2469/faj.v58.n2.2522

17. Liu, J., Nissim, D., \& Thomas, J. (2002). Equity valuation using multiples. Journal of Accounting Research, 40(1), 135-172. https://doi.org/10.1111/1475-679X.00042

18. Malkiel, B. G. (2013). Asset management fees and the Growth of finance. Journal of Economic Perspectives, 27(2), 97-108. https://doi.org/10.1257/jep.27.2.97

19. Yoo, Y. K. (2006). The valuation accuracy of equity valuation using a combination of multiples. Review of Accounting and Finance, 5, 108-123. https://doi.org/10.1108/14757700610668958

20. Zask, E. (2000). Hedge funds: a methodology for hedge funds valuation. Journal of Alternative Investments, 3(3), 43-46. https://doi.org/10.3905/jai.2000.318965 


\section{APPENDIX}

Table 1. Descriptive statistics for the whole sample (mln of USD)

\begin{tabular}{|c|c|c|c|c|c|c|}
\hline Variable & $N^{\circ} \mathrm{Obs}$ & Mean & Median & Std Dev & Min & $\operatorname{Max}$ \\
\hline Market Cap $(\$ \mathrm{mln})$ & 445 & 5,533 & 2,257 & 9,278 & 11 & 82,364 \\
\hline AUM (\$ mln) & 445 & 287,949 & 69,212 & 658,215 & 641 & $6,288,195$ \\
\hline Price/AUM & 445 & $3.01 \%$ & $2.50 \%$ & $2.35 \%$ & $0.15 \%$ & $15.40 \%$ \\
\hline Fees/AUM & 445 & $1.04 \%$ & $0.80 \%$ & $0.78 \%$ & $0.05 \%$ & $4.26 \%$ \\
\hline EBIT Margin & 445 & $27.84 \%$ & $28.20 \%$ & $16.83 \%$ & $-96.08 \%$ & $84.71 \%$ \\
\hline Net Margin & 445 & $16.84 \%$ & $17.37 \%$ & $14.56 \%$ & $-98.79 \%$ & $65.16 \%$ \\
\hline Revenues growth & 394 & $8.18 \%$ & $6.31 \%$ & $23.24 \%$ & $-63.42 \%$ & $173.67 \%$ \\
\hline EBIT growth & 394 & $-1.79 \%$ & $6.15 \%$ & $226.93 \%$ & $-2459.14 \%$ & $1982.38 \%$ \\
\hline Net Income Growth & 394 & $1.15 \%$ & $6.68 \%$ & $364.99 \%$ & $-2813.27 \%$ & $5385.93 \%$ \\
\hline
\end{tabular}

Table 2. Descriptive statistics split between US and European firms (mln of USD)

\begin{tabular}{|c|c|c|c|c|c|c|c|c|c|c|c|c|}
\hline & \multicolumn{6}{|c|}{ US } & \multicolumn{6}{|c|}{$E U$} \\
\hline Variable & \# & Mean & Median & Std Dev & Min & $\operatorname{Max}$ & \# & Mean & Median & Std Dev & Min & $\operatorname{Max}$ \\
\hline Market Cap $(\$ \mathrm{mln})$ & 288 & 7,278 & 2,825 & 10,976 & 11 & 82,364 & 157 & 2,330 & 1,559 & 2,810 & 33 & 17,081 \\
\hline AUM (\$ mln) & 288 & 395,428 & 125,051 & 784,418 & 641 & $6,288,195$ & 157 & 90,792 & 38,131 & 198,638 & 1,608 & $1,710,915$ \\
\hline Price/AUM & 288 & $2.61 \%$ & $2.28 \%$ & $1.86 \%$ & $0.22 \%$ & $12.03 \%$ & 157 & $3.73 \%$ & $2.75 \%$ & $2.93 \%$ & $0.15 \%$ & $15.40 \%$ \\
\hline Fees/AUM & 288 & $0.94 \%$ & $0.67 \%$ & $0.72 \%$ & $0.14 \%$ & $4.18 \%$ & 157 & $1.23 \%$ & $0.95 \%$ & $0.84 \%$ & $0.05 \%$ & $4.26 \%$ \\
\hline EBIT Margin & 288 & $29.24 \%$ & $30.79 \%$ & $14.66 \%$ & $-96.08 \%$ & $63.50 \%$ & 157 & $25.27 \%$ & $23.31 \%$ & $20.02 \%$ & $-42.68 \%$ & $84.71 \%$ \\
\hline Net Margin & 288 & $16.34 \%$ & $17.97 \%$ & $12.03 \%$ & $-98.79 \%$ & $43.15 \%$ & 157 & $17.76 \%$ & $16.63 \%$ & $18.32 \%$ & $-62.28 \%$ & $65.16 \%$ \\
\hline Revenues growth & 255 & $9.30 \%$ & $6.45 \%$ & $24.99 \%$ & $\begin{array}{l}-58.21 \% \\
\end{array}$ & $173.67 \%$ & 139 & $6.13 \%$ & $6.18 \%$ & $19.54 \%$ & $-63.42 \%$ & $55.19 \%$ \\
\hline EBIT growth & 255 & $-1.10 \%$ & $6.24 \%$ & $251.19 \%$ & $-2459.14 \%$ & $1982.38 \%$ & 139 & $-3.06 \%$ & $4.69 \%$ & $173.08 \%$ & $-1607 \%$ & $595.65 \%$ \\
\hline Net Income growth & 255 & $6.88 \%$ & $7.67 \%$ & $419.66 \%$ & $-2813.3 \%$ & $5385.93 \%$ & 139 & $-9.35 \%$ & $5.01 \%$ & $234.65 \%$ & $-2139.09 \%$ & $801.12 \%$ \\
\hline
\end{tabular}

Table 3. Descriptive statistics of the winsorized variables

\begin{tabular}{|c|c|c|c|c|c|}
\hline Variable & $N^{\circ} \mathrm{Obs}$ & Mean & Std Dev & Min & $\operatorname{Max}$ \\
\hline EBIT Margin & 445 & $28.04 \%$ & $15.32 \%$ & $-17.38 \%$ & $68.46 \%$ \\
\hline Net Margin & 445 & $17.13 \%$ & $12.80 \%$ & $-22.21 \%$ & $55.26 \%$ \\
\hline Revenues growth & 394 & $8.05 \%$ & $21.62 \%$ & $-39.08 \%$ & $89.15 \%$ \\
\hline EBIT growth & 394 & $9.34 \%$ & $77.40 \%$ & $-205.55 \%$ & $289.93 \%$ \\
\hline Net Income growth & 394 & $1.19 \%$ & $122.79 \%$ & $-517.18 \%$ & $359.40 \%$ \\
\hline
\end{tabular}

Table 4. Pair-wise Pearson Correlation matrix

\begin{tabular}{|c|c|c|c|c|c|c|c|c|c|}
\hline Variable & $\log$ Fess/AUM & EBIT Margin & Net Margin & $\log A U M$ & Dummy_US & $D \_2012$ & Rev. growth & EBIT growth & Net Inc Growth \\
\hline Log Fess/AUM & 1 & & & & & & & & \\
\hline EBIT Margin & -0.0713 & 1 & & & & & & & \\
\hline Net Margin & -0.0873 & $0.7581^{*}$ & 1 & & & & & & \\
\hline Log AUM & $-0.2348^{*}$ & -0.0042 & -0.0770 & 1 & & & & & \\
\hline Dummy_US & $-0.1536^{*}$ & $0.1295^{*}$ & -0.0559 & $0.3131^{*}$ & 1 & & & & \\
\hline$D_{-} 2012$ & $-0.1385^{*}$ & $0.0949 *$ & $0.1365^{*}$ & $0.1405^{*}$ & -0.000 & 1 & & & \\
\hline Revenues growth & 0.0276 & 0.0890 & 0.0465 & -0.0687 & 0.0597 & 0.0527 & 1 & & \\
\hline EBIT growth & 0.0550 & $0.2517^{*}$ & $0.2036^{*}$ & -0.0403 & -0.0198 & 0.0329 & $0.4310^{*}$ & 1 & \\
\hline Net Income growth & 0.0036 & $0.2827^{*}$ & $0.3052 *$ & 0.0435 & -0.0296 & $0.1166^{*}$ & $0.2443^{*}$ & $0.5628^{*}$ & 1 \\
\hline
\end{tabular}

Note: * Indicates statistical significance at 0.05 significant level.

VIRTUS 
Table5. Determinants of the P/AUM multiple. Fixed Effect (FE) model with cluster-robust standard errors (T-stats in parenthesis)

\begin{tabular}{|c|c|c|c|c|}
\hline Variables & Model 1 & Model 2 & Model 3 & Model 4 \\
\hline Log Fees/AUM & $\begin{array}{c}0.4782^{* * \mathrm{k}} \\
(4.89) \\
\end{array}$ & $\begin{array}{c}0.5321^{* * *} \\
(4.78)\end{array}$ & $\begin{array}{c}0.5347^{* *} \\
(5.01)\end{array}$ & $\begin{array}{c}0.5575^{\ldots * *} \\
(5.07)\end{array}$ \\
\hline Net margin & $\begin{array}{l}.3173^{* * *} \\
(5.65)\end{array}$ & $\begin{array}{c}1.2227^{\text {*** }} \\
(5.25)\end{array}$ & $\begin{array}{c}1.2496^{* * *} \\
(5.18)\end{array}$ & $\begin{array}{c}1.2111^{* * *} \\
(4.96)\end{array}$ \\
\hline D_2012 & & $\begin{array}{c}0.0602 \\
(1.28)\end{array}$ & & $\begin{array}{c}0.0824 \\
(1.60) \\
\end{array}$ \\
\hline Revenues Growth & & & $\begin{array}{c}0.0092 \\
(0.09)\end{array}$ & $\begin{array}{c}0.0264 \\
(0.27)\end{array}$ \\
\hline $\log A U M$ & & & $\begin{array}{c}-0.042 \\
(-0.70) \\
\end{array}$ & $\begin{array}{c}-0.1173 \\
(-1.58) \\
\end{array}$ \\
\hline Constant & $\begin{array}{l}-1.712^{\cdots * *} \\
(-3.74)\end{array}$ & $\begin{array}{c}-1.4695^{* * *} \\
(-2.86)\end{array}$ & $\begin{array}{c}-0.3535 \\
(-0.28)\end{array}$ & $\begin{array}{l}1.6069 \\
(0.98)\end{array}$ \\
\hline$F$ & 20.64 & 13.07 & 14.24 & 12.36 \\
\hline Within R2 & 0.2659 & 0.2730 & 0.2754 & 0.2876 \\
\hline Between R2 & 0.6070 & 0.5879 & 0.5995 & 0.5361 \\
\hline Overall $R 2$ & 0.5544 & 0.5467 & 0.5708 & 0.5206 \\
\hline
\end{tabular}

Note: *, ** Indicates statistical significance at $5 \%$ and $1 \%$ level.

Table 6. Determinants of the P/AUM multiple. Random Effect (RE) model cluster robust standard errors. T-stats in parenthesis

\begin{tabular}{|c|c|c|c|c|}
\hline Variables & Model 1 & Model 2 & Model 3 & Model 4 \\
\hline Log FEES/AUM & $\begin{array}{c}0.5475^{* * *} \\
(6.37)\end{array}$ & $\begin{array}{c}0.5872^{* * *} \\
(5.97)\end{array}$ & $\begin{array}{c}0.5970^{* * * *} \\
(6.65)\end{array}$ & $\begin{array}{c}0.6219^{* * *} \\
(6.58)\end{array}$ \\
\hline Net margin & $\begin{array}{c}1.4092^{* * *} \\
(5.87)\end{array}$ & $\begin{array}{c}1.3068^{* * *} \\
(5.53)\end{array}$ & $\begin{array}{c}1.4111^{* * * *} \\
(6.67)\end{array}$ & $\begin{array}{c}1.3385^{* * *} \\
(6.17)\end{array}$ \\
\hline Dummy_US & & $\begin{array}{c}-0.1502 \\
(-1.04)\end{array}$ & & $\begin{array}{c}-0.0819 \\
(-0.55)\end{array}$ \\
\hline D_2012 & & $\begin{array}{c}0.0655 \\
(1.43)\end{array}$ & & $\begin{array}{c}0.0628 \\
(1.41)\end{array}$ \\
\hline Revenues growth & & & $\begin{array}{c}0.0239 \\
(0.23)\end{array}$ & $\begin{array}{c}0.0256 \\
(0.25)\end{array}$ \\
\hline $\log A U M$ & & & $\begin{array}{c}-0.0523 \\
(-1.45)\end{array}$ & $\begin{array}{c}-0.0711 \\
(-1.73)\end{array}$ \\
\hline Constant & $\begin{array}{c}-1.4102^{* * *} \\
(-3.71)\end{array}$ & $\begin{array}{c}-1.1442^{* * *} \\
(-2.86)\end{array}$ & $\begin{array}{l}0.1562 \\
(0.21)\end{array}$ & $\begin{array}{l}0.7747 \\
(0.88)\end{array}$ \\
\hline Wald Chi2 & 53.61 & 58.54 & 116.62 & 113.68 \\
\hline Within R2 & 0.2656 & 0.2730 & 0.2753 & 0.2854 \\
\hline Between R2 & 0.6013 & 0.5846 & 0.6004 & 0.5784 \\
\hline Overall $R 2$ & 0.5518 & 0.5416 & 0.5712 & 0.5534 \\
\hline
\end{tabular}

Note: *, ** Indicates statistical significance at $5 \%$ and $1 \%$ level. 